Blaxter, K. L. \& Wilson, R. S. (1963). Anim. Prod. 5, 27.

Campling, R. C. (1964). Proc. Nutr. Soc. 23, 80.

Cooper, J. P., Tilley, J. M. A., Raymond, W. F. \& Terry, R. A. (1962). Nature, Lond., 195, 1276.

Dent, J. W. (1963). Proc. I 962 Crop Conference, National Institute of Agricultural Botany, Cambridge.

Dodsworth, T. L. \& Campbell, W. H. McK. (1953). J. agric. Sci. 43, г66.

Evans, R. E. (1960). Bull. Minist. Agric., Lond., no. $4^{8 .}$

Harris, C. E. \& Raymond, W. F. (1963). F. Brit. Grassl. Soc. 18, 204.

McMeekan, C. P. (I960). Proc. int. Grassl. Congr. vilı. Reading, p. $2 \mathrm{I}$.

Minson, D. J., Harris, C. E., Raymond, W. F. \& Milford, R. (1964). F. Brit. Grassl. Soc. (In the Press.)

Morrison, J. (1960). Proc. int. Grassl. Congr. vin. Reading, p. 693.

Mott, G. O. (1960). Proc. int. Grassl. Congr. virr. Reading, p. 606.

Murdoch, J. C. (1960). F. Brit. Grassl. Soc. 15, 70.

Roe, R. \& Mottershead, B. E. (1962). Nature, Lond., 193, 255.

Rook, J. A. F. (1964). Proc. Nutr. Soc. 23, 71.

Shepperson, G. (1960). Proc. int. Grassl. Congr. viIr. Reading, p. 704.

Tayler, J. C. \& Deriaz, R. E. (1963). F. Brit. Grassl. Soc. 18, 29.

Tilley, J. M. A. \& 'Terry, R. A. (1963). F. Brit. Grassl. Soc. 18, 104.

Wilson, R. F. (1962). Exp. Grassl. Res. Inst., Hurley, no. 14, p. 59.

Woodman, H. E. \& Norman, D. B. (1932). J. agric. Sci. 22, 852.

\title{
Utilization of the metabolizable energy of grass*
}

\section{By K. L. Blaxter, Hannah Dairy Research Institute, Ayr}

A convenient way of measuring the energy which grass or indeed any food supplies to an animal is as its metabolizable energy. Metabolizable energy is defined as the heat of combustion of the food less the heat of combustion of the faeces, the urine and the combustible gas, mostly methane, which are produced from it. It is usually expressed as kcal metabolizable energy/g dry food and the definition is strictly in terms of measurable quantities, measurement of methane involving use of a respiration chamber. The calorific value of the dry matter of grass, or the organic matter of grass, is subject to relatively little variation. Hutton ( 1961,1962 ), for example, found the calorific value of pasture grass to range from $4 \cdot 32$ to $4 \cdot 56 \mathrm{kcal} / \mathrm{g}$ dry matter, a variation largely associated with the protein content of the grass. The main determinant of the metabolizable energy of grass per unit dry weight or per unit organic matter is undoubtedly the loss of energy in the faeces. Faecal losses of energy rarely fall below $15 \%$ but can rise to $60 \%$ of the heat of combustion of the grass. Loss of energy as methane rarely exceeds $10 \%$ of the energy of the grass and loss of energy in urine rarely exceeds $9 \%$ of the energy of the grass. Losses of energy both in urine and as methane vary over a considerably smaller absolute range than does the faecal loss of energy. Indeed, the metabolizable energy of grass and grassland products can be estimated with little error by multiplying the apparently digested energy of grass (heat of combustion of grass less heat of combustion of faeces) by 0.82 . This factor applies to artificially dried grasses varying in protein content from $5^{\circ} \mathrm{I}$ to $22.6 \%$ (Armstrong, Blaxter \& Waite, I 964), to a dried lucerne (Bateman \& Blaxter, I964), to grass silages (J. L. Clapperton, r963, unpublished) and to fresh pasture grass (Blaxter, Ekern \& Sawers, I 963 , unpublished). Alternatively, but with a slightly greater error, the metabolizable energy of grass can be estimated by assuming that each $\mathrm{g}$ digested organic matter has a metabolizable energy value of $3.6 \mathrm{kcal}$.

\footnotetext{
*Read at the joint meeting of The Nutrition Society and the British Grassland Society in London on 5 December 1963. Also published in the foumal of the British Grassland Society, Vol. I9, No. I, March 1964 .
} 
Even so, such indirect methods of estimating metabolizable energy still involve a biological test in the form of a digestion trial. In our laboratory attempts have been made to estimate the metabolizable energy of grassland products from their chemical composition alone, commencing with a study of a series of artificially dried pasture grasses (Armstrong, I964; Blaxter \& Wilson, r963). Metabolizable energy was determined calorimetrically and was related to the composition of the grass as determined by methods developed in Dr Waite's laboratory (Waite \& Gorrod, I959a, $b$; Waite, Johnston \& Armstrong, 1964). It suffices to state that the chemical component in dried herbage which showed maximal correlation with metabolizable energy was its lignin content determined by a modification of the method of Ellis, Matrone \& Maynard ( 1946). When the metabolizable energy/g organic matter of grasses ranging in metabolizable energy from $2 \cdot 2$ to $3.5 \mathrm{kcal} / \mathrm{g}$ organic matter was related to the

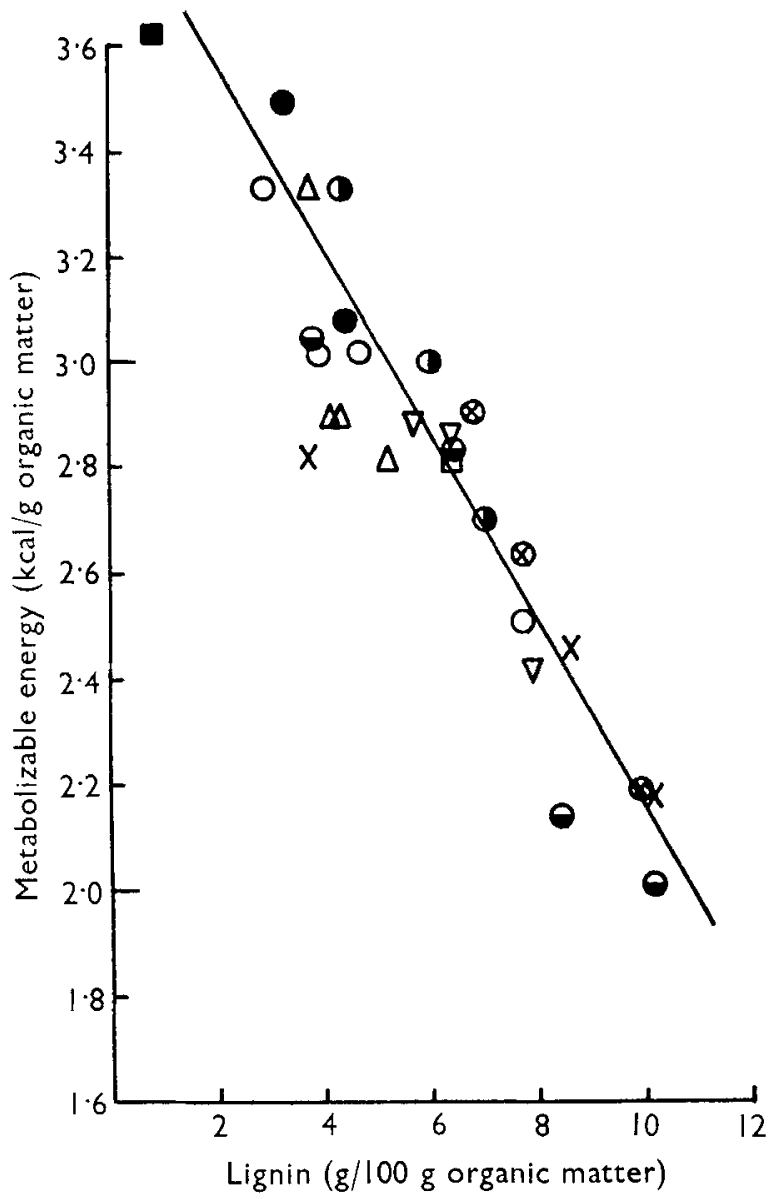

Fig. I. Relation between the lignin content of the organic matter of a series of grassland products, including fresh grass, artificially dried grasses, pelleted grasses, and silages, and their metabolizable energy expressed on an organic-matter basis. A value for a sample of flaked maize has been included for comparative purposes. The line is that determined by Armstrong et al. (1964) using the first four materials listed below.

Dried grasses and hays: $O, \mathrm{~S}_{23}$ ryegrass;, $\mathrm{S}_{24}$ ryegrass; $O, \mathrm{~S}_{37}$ cocksfoot; $\otimes, \mathrm{S}_{4} 8$ timothy; $\ominus$, commercial mixtures; $\square$, lucerne; $\triangle$, fresh grass; $\nabla$, silages; $X$, pelleted grass; $\square$, flaked maize. 
lignin content of the organic matter, the residual standard deviation was only $\pm 4.7 \%$ of the mean value (Armstrong et al. 1964). The relationship is shown in Fig. I, in which, in addition, results have been included for a lucerne sample, three silage samples, three samples of pelleted grass and four further samples of artificially dried herbage or hay. The metabolizable energy values all refer to direct determinations. With the exception of the values for fresh grass, which were obtained at higher nutritional levels, all determinations refer to the maintenance level of feeding. Fig. I shows that the general relationship obtained with dried pasture grasses applies equally to young lucerne, silages and to two of the pelleted foods. The third pelleted food which was of high-quality dried grass had a lower metabolizable energy than expected owing to a large faecal loss of energy.

In this regard laboratory methods involving a fermentation in vitro have been used to determine a residual fraction in herbage and hay samples which has then with some success been correlated with the apparent digestibility of the sample. This correlation, together with the general relationship between metabolizable energy and apparently digested energy already referred to, could no doubt be used to estimate metabolizable energy by a laboratory procedure which is more simple than that of determining lignin by the $72 \% \mathrm{H}_{2} \mathrm{SO}_{4}$ method. Chemical methods are usually more reproducible as between laboratories than is a method involving the use of mixed

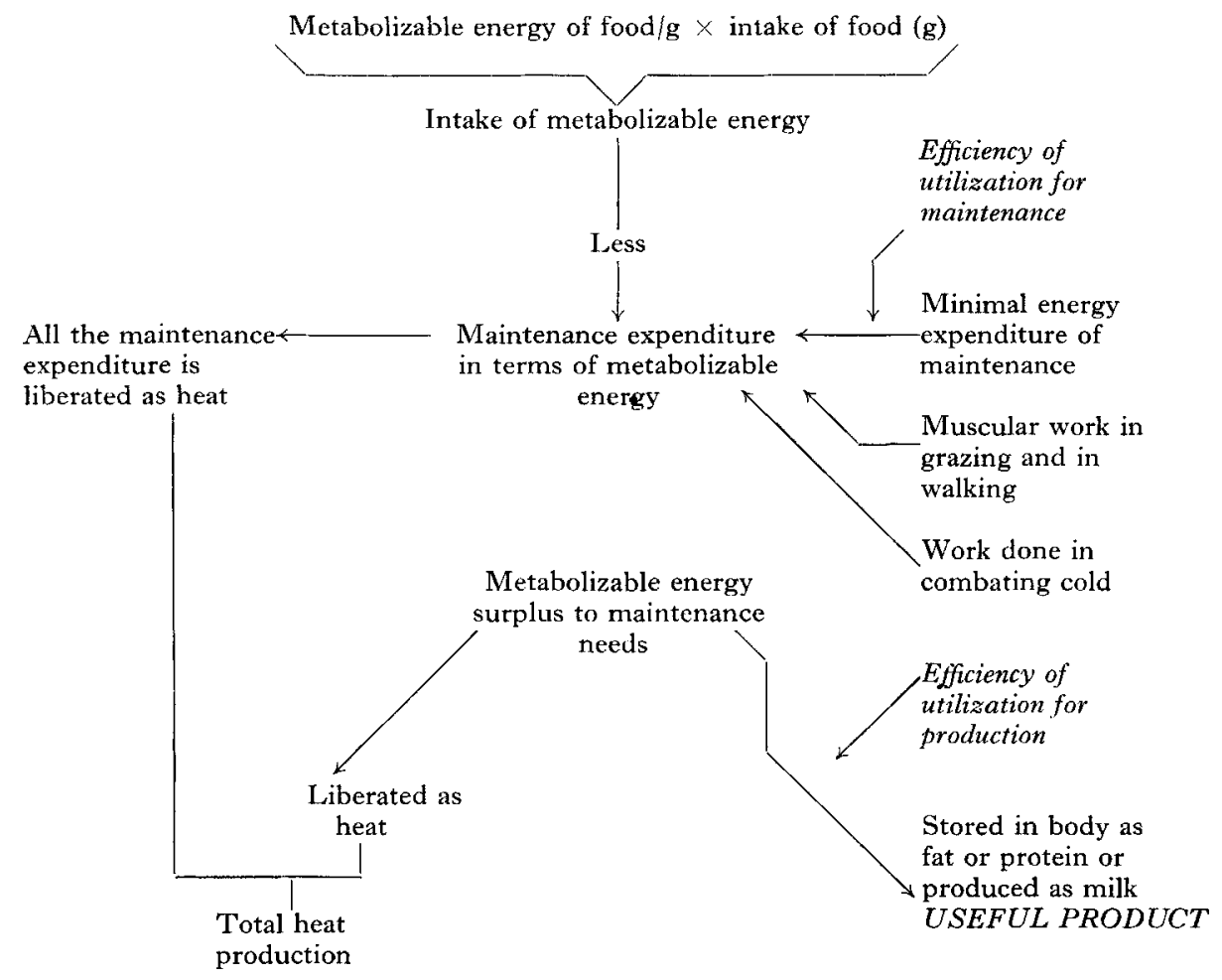

Fig. 2. A scheme for relating animal production to food value, which indicates the determinants of production. 
cultures of micro-organisms and reference of each result to some standard herbage, but in deciding between alternative methods of estimating metabolizable energy for routine application the lower precision and greater speed attained by fermentation methods may well prevail.

The metabolizable energy of grass expressed as $\mathrm{kcal} / \mathrm{g}$ grass, though it can be determined or estimated relatively easily, is not, however, a simple common denominator from which animal production can be inferred by direct proportion. This is particularly true where animals graze or are fed on grassland products ad lib., and the reasons can be seen by reference to Fig. 2. If we interpret the term utilization widely, then the utilization of the metabolizable energy of grass is the sum of all those factors that determine the production of saleable animal product from grass. Fig. 2 shows that there are five determinants of the animal production that can be attained from grassland produce:

(1) the metabolizable energy/unit weight of the food consumed;

(2) the weight of food consumed;

(3) the energy expended by the animal in maintaining itself and in its various activities;

(4) the ability of the metabolizable energy of the particular food to meet these energy expenditures of maintenance;

(5) the ability of that part of the metabolizable energy supplied by the food that is surplus to the inexorable demands of maintenance to promote synthesis of meat, fat and milk.

Table 1. Interrelations between the metabolizable energy of food expressed as a percentage of its gross energy $(Q)$, the voluntary intake of food dry matter $(D M)$ and the utilization of metabolizable energy for both maintenance and production by sheep

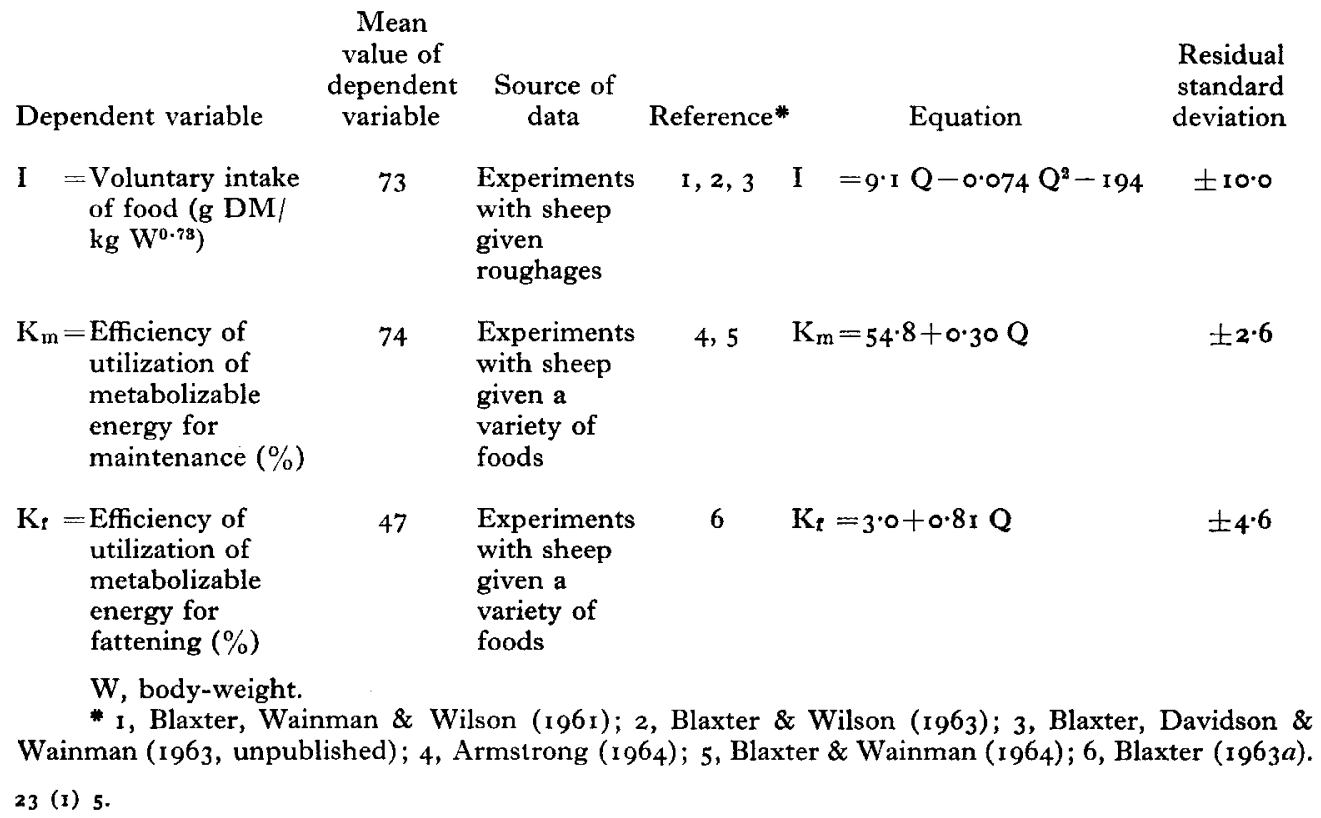


Some of these five factors are interrelated, and during the last few years my colleagues and I have examined such interrelationships. Using as the independent variable the metabolizable energy as a percentage of the gross energy of food (Q), thereby discounting the variations in the heat of combustion of food per unit dry weight, we have found in experiments with sheep the general relationships shown in Table $\mathrm{r}$. The three relationships in Table I imply that, if the metabolizable energy of food/g and the energy expenditure of maintenance are known, an estimate can be made of the likely production attained when the food is given ad lib. The joint solution to the equation in $\mathrm{Q}$ obtained on combining the three equations above is shown in Fig. 3 from which it is evident that, if maintenance costs are assumed to be those

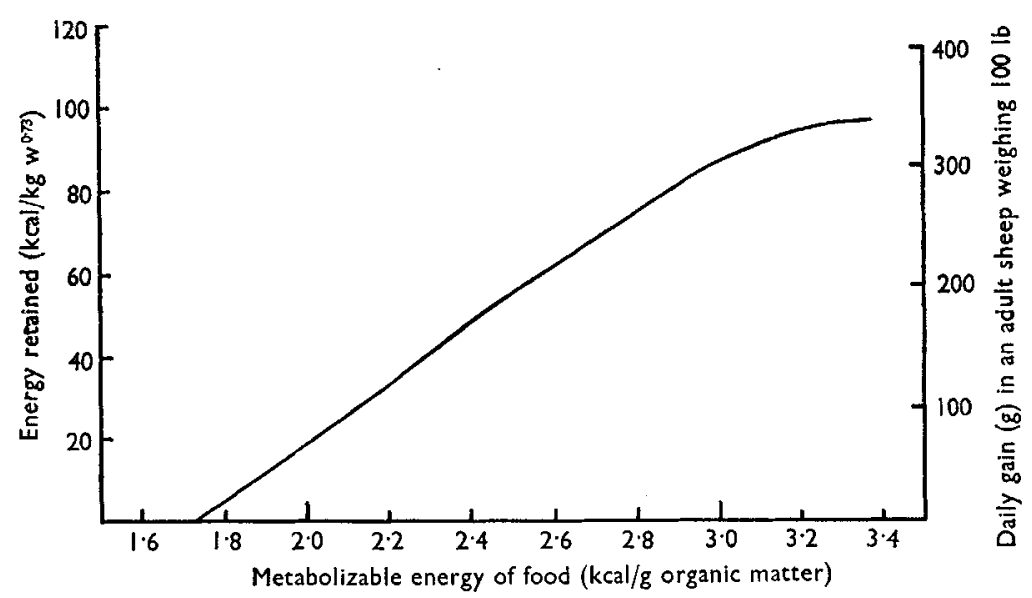

Fig. 3. Relation between the metabolizable energy value of conserved grassland products and the animal production attained when these are given $a d$ lib. to sheep. The figure was derived solely from the regressions shown in Table $\mathrm{I}$, and no account has been taken of the fall in the metabolizable energy of unit food when the intake is considerably above maintenance.

measured in a calorimeter, no production occurs when food with a metabolizable energy of $\mathrm{I} \cdot 7 \mathrm{kcal} / \mathrm{g}$ is given ad lib., and that as the metabolizable energy of food rises to $2.8 \mathrm{kcal} / \mathrm{g}$ production rises, rapidly at first, and thereafter more slowly. Errors of estimate are, however, quite large, most uncertainty arising from uncertainty about the intake of food.

The general statement in Fig. 3 applies to grassland herbage preserved by making it into hay or by drying it, and is probably the best indication available of the potential productivity of grass conserved by conventional means when it is given as sole food. The indication can be grossly in error when applied to grassland products other than dried herbage, it may be in error when applied to fresh herbage and is certainly not the best index of the value of grassland products when they are supplemented with other foods. Table 2 gives results obtained calorimetrically with a meadow fescue made into pellets and with a poor silage, both of which had a metabolizable energy $/ g$ dry matter of $2.20 \mathrm{kcal}$. The utilization of metabolizable energy of the pellets for production was higher and the utilization of the metabolizable energy of the silage for maintenance was lower than expected, but, even so, the good appetite for the 
Table 2. Nutritive value of a pelleted dried herbage and of a poor-quality silage compared with expectations based on the equations in Table $\mathrm{I}^{*}$

\begin{tabular}{|c|c|c|c|}
\hline Material & $\begin{array}{l}\text { Pelleted } \\
\text { artificially } \\
\text { dried meadow } \\
\text { fescuet }\end{array}$ & $\begin{array}{l}\text { Poor-quality } \\
\text { silaget }\end{array}$ & $\begin{array}{l}\text { Values } \\
\text { expected } \\
\text { from the } \\
\text { equations in } \\
\text { Table I }\end{array}$ \\
\hline $\begin{array}{l}\text { Metabolizable energy/g } \\
\text { dry matter }(\mathrm{kcal})\end{array}$ & $2 \cdot 20$ & $2 \cdot 20$ & $(2 \cdot 20)$ \\
\hline $\begin{array}{l}\text { Voluntary intake } \\
\left(\mathrm{g} / \mathrm{kg} \mathrm{W}^{0.73} \text { day }\right)\end{array}$ & 108 & 34 & 69 \\
\hline $\begin{array}{l}\text { Metabolizable energy } \\
\text { intake (kcal } / \mathrm{kg} \mathrm{W}^{0.73} \text { day) }\end{array}$ & $23^{8}$ & 75 & I 52 \\
\hline $\begin{array}{l}\text { Efficiency of utilization of } \\
\text { metabolizable energy } \\
\text { for maintenance }(\%)\end{array}$ & $69 \cdot 2$ & $6 \mathrm{I} \cdot 4$ & $69 \cdot 7$ \\
\hline $\begin{array}{l}\text { Metabolizable energy available } \\
\text { above maintenance } \\
\text { (kcal } / \mathrm{kg} \mathrm{W0.73} \text { day) }\end{array}$ & I 58 & $-I_{4}$ & \\
\hline $\begin{array}{l}\text { Efficiency of utilization of } \\
\text { metabolizable energy } \\
\text { for production }(\%)\end{array}$ & $48 \cdot 2$ & $\begin{array}{l}\text { Not possible } \\
\text { to determine }\end{array}$ & 43.5 \\
\hline $\begin{array}{l}\text { Energy retained } \\
\quad\left(\mathrm{kcal} / \mathrm{kg} \mathrm{W} \mathrm{W}^{0.73} \text { day }\right)\end{array}$ & 76 & -9 & 38 \\
\hline
\end{tabular}

pellets and the poor appetite for the silage were clearly the more important determinants of the excellent energy retention obtained with pellets and the poor results noted with the silage. It can be stated, generally, that for foods of any one class, variation in the voluntary intake from food to food is usually a more important factor in accounting for variation in animal production than is variation from food to food in the utilization of metabolizable energy. Dr Campling (r964) will no doubt deal with these aspects in more detail.

A further illustration that the general statements about the potential productivity of grass given in Table $\mathrm{I}$ apply only to grass conserved in conventional ways has been obtained with fresh grass. Studies we have made show that when animals are given the same amount of the same grass, either fresh or artificially dried, they lose more energy as heat and retain less energy in their bodies with the former than with the latter (Blaxter, Ekern \& Sawers, 1963, unpublished). The reason for this is not known; it is clearly pertinent to measures of the productivity of grazed herbage.

With these limitations and defects in our knowledge in mind, a simple measure of the nutritive value of grassland produce can be made by dividing the metabolizable energy consumed by the maintenance requirement for metabolizable energy. This takes into account the first four of the factors listed earlier, but neglects variation in the efficiency of utilization of metabolizable energy surplus to maintenance demands. It also emphasizes the important part that maintenance costs play in determining animal output. 
When animals are kept in comfortable conditions in good buildings, they take little exercise and have minimal maintenance needs. Their energy requirements are probably much the same as those measured in respiration chambers. Considerable information is now available to show how the maintenance energy requirements of sheep vary from age to age of animal and from individual to individual (Blaxter, 1962). The overall variation with age is about $\pm 18 \%$ of a mean value for a yearling sheep and individual variation is about \pm II $\%$ of the mean at a given age. The average maintenance cost of a group of animals of a given age kept in good buildings and given conserved or fresh grass is thus subject to little variation.

Out-of-doors, animals move about more, and for a given amount of food consumed they have to expend more energy because they must bite off herbage rather than merely prehend it. Furthermore, out-of-doors they are subjected to rain, wind and sunshine and to greater extremes of air temperature and incoming infrared radiation than they ever experience indoors. It might be expected, therefore, that the maintenance requirements of grazing animals will generally exceed those of animals indoors, and could well vary over a much greater range owing to the type of terrain, the availability of herbage and the prevailing climatic conditions. Utilization of metabolizable energy expressed in terms of animal-product output per metabolizable energy intake must be lower.

Attempts made to measure maintenance expenditures of energy out-of-doors have been of two types. In the first the intake of digested organic matter by normal grazing animals has been determined and related to the body size and measured production of the stock. In the second, measurements of the energy expended by

Table 3. Estimates of the maintenance requirements of sheep and cattle made under natural grazing conditions compared with the maintenance requirements to be expected from calorimetric experiments

\begin{tabular}{|c|c|c|c|c|c|}
\hline Animal & Country & $\begin{array}{l}\text { Estimated in } \\
\text { terms of } \\
\text { digested } \\
\text { organic matter } \\
\text { (lb) }\end{array}$ & $\begin{array}{c}\text { Estimate } \\
\text { expressed as } \\
\text { metabolizable } \\
\text { energy } \\
\text { (kcal/day) }\end{array}$ & $\begin{array}{c}\text { Calculated } \\
\text { from indoor } \\
\text { experiments } \dagger \\
(\mathrm{kcal} / \mathrm{day})\end{array}$ & Reference \\
\hline Sheep & $\begin{array}{l}\text { New Zealand } \\
\text { New Zealand } \\
\text { New Zealand } \\
\text { Scotland } \\
\text { Australia }\end{array}$ & $\begin{array}{l}I \cdot 47 \\
I \cdot 63 \\
I \cdot 36 \\
I \cdot 02 \\
I \cdot 23\end{array}$ & $\left.\begin{array}{ll}2 & 500 \\
2 & 771 \\
2 & 312 \\
1 & 734 \\
2 & 091\end{array}\right\}$ & $\sim_{1500}$ & $\begin{array}{l}I \\
1 \\
I \\
2 \\
3\end{array}$ \\
\hline Cow & $\begin{array}{l}\text { USA } \\
\text { New Zealand } \\
\text { New Zealand } \\
\text { Scotland } \S\end{array}$ & $\begin{array}{r}11.5 \\
12.4 \\
14.7 \\
7.2\end{array}$ & $\left.\begin{array}{l}18600 \\
21100 \\
25000 \\
12200\end{array}\right\}$ & $\sim_{1} \times 500$ & $\begin{array}{l}4 \\
5 \\
6 \\
7\end{array}$ \\
\hline Calf & England & 10.5 & 17800 & $\sim_{13500}$ & 8 \\
\hline
\end{tabular}


animals in walking, eating and combatting the vicissitudes of the environment have been combined with determinations of the patterns of daily activity of stock and meteorological information to estimate the magnitude of the energy expenditure.

Table 3, which is not an inclusive summary, indicates that some estimates of the maintenance needs of sheep at pasture grossly exceed the maintenance costs determined indoors in calorimeters. The same is true of the experiments with milking cows and with growing cattle. Not all experiments, however, show this gross divergence, notably those made by Corbett et al. (I96I) under close-folding conditions. It is possible that systematic errors may be involved in some of the experiments, but these could hardly be of such a magnitude as to account for discrepancies between expectation and observation of $100 \%$. It must be concluded that maintenance requirements of animals at pasture are very high, a fact which has considerable implication with respect to any attempts to describe the utilization of the metabolizable energy of herbage in the field.

The additional movement of animals at pasture together with the measured energy costs of walking as determined in cattle (Hall \& Brody, 1934) and in sheep (Clapperton, 1961, I964) are not sufficient to account for the discrepancy between 'outdoor' and 'indoor' estimates of maintenance needs. With most grazing stock, maintenance requirements would not be expected to exceed by $10 \%$ those of similar animals kept indoors. The energy cost of shearing off pasture during grazing by the sheep has been assessed by Graham (1962) as $0.6-0.8 \mathrm{kcal} / \mathrm{h} \mathrm{kg}$ sheep. This seems very high, for an hour's biting of herbage by a sheep is then equivalent to the sheep walking $1000 \mathrm{~m}$. Even if this figure is accepted, however, a $100 \mathrm{lb}$ sheep grazing for $6 \mathrm{~h}$ daily expends $190 \mathrm{kcal}$ only in additional work of biting. If the sheep walks I mile/day, it would expend a further $43 \mathrm{kcal}$. Together these two expenditures account for $230 \mathrm{kcal}$, which is about $\mathrm{I} 8 \%$ of the minimal maintenance requirement of about $\mathrm{r} 300 \mathrm{kcal}$. Clearly the discrepancies apparent in Table 3 cannot be explained in terms of the measured cost of grazing.

In discussing the results of their experiments with sheep Coop \& Hill (1962) suggested that the weather might be in part responsible for the discrepancy between calorimetric results and pasture trials, and in this regard Lambourne (1963) found that, particularly in thin sheep, maintenance requirements rose in winter. Direct studies of the effects of cold climatic conditions on energy expenditure by sheep and cattle, when the term 'cold' is used to express the joint effects of wind, air temperature, rain and infrared radiation, support this suggestion. Wind, in particular, has very considerable effects on the heat losses of sheep and cattle (Blaxter, Joyce $\&$ Wainman, I963; Blaxter \& Joyce, 1964). These effects have been reviewed (Blaxter, $1963 b)$ and it suffices to state that, even when air temperatures are above $0^{\circ}$, a combination of high wind with rain can increase maintenance needs by a factor of up to threefold. The greatest increases occur in sheep immediately after shearing, when it is possible, even at air temperatures of $7^{\circ}$, to produce a combination of wind and rain conditions which result in such a stress that the sheep can no longer maintain thermal equilibrium, its rectal temperature falling continuously to values as low as $32^{\circ}$. 
Whether an effect of weather conditions is the sole reason for the discrepancy between calorimetric and outdoor estimates of maintenance needs is not known. Other factors may be involved, notably the marked increase in heat production during the initial stages of eating a meal, as noted by Blaxter \& Joyce (I964). Such an increase might have a greater proportional effect on maintenance needs in a grazing animal than in one given two meals daily. Again, the higher heat production from fresh compared with dried herbage may be relevant, and it may be necessary to consider the suggestion of Lambourne \& Reardon (1963) that an endocrine stimulation of metabolism is evoked by outdoor conditions with sparse grazing.

In conclusion, it appears that more information than is at present available is required before it is possible to predict animal performance precisely from a knowledge of the metabolizable energy of grass or grassland products per $g$ dry weight. The way in which the metabolizable energies of dried grass and grass hays are utilized under ad lib. conditions of feeding and in surroundings which are not very different from those of a calorimeter can, however, be predicted sufficiently precisely for most practical purposes from information already available. With grass silages, pelleted grasses and possibly with legumes, such generalizations break down; with grazed grass in many outdoor environments, to attempt to predict from the metabolizable energy of unit weight of herbage the final amount of animal product realized in no way approaches a practical proposition. Much more information is needed about the utilization of energy by ruminants grazing under natural conditions before we can express the art of the grazier in rational terms.

\section{REFERENCES}

Armstrong, D. G. (1964). F. agric. Sci. (In the Press.)

Armstrong, D. G., Blaxter, K. L. \& Waite, R. (1964). F. agric. Sci. (In the Press.)

Bateman, J. V. \& Blaxter, K. L. (1964). F. agric. Sci. (In the Press.)

Blaxter, K. L. (1962). Brit. F. Nutr. 16, 615.

Blaxter, K. L. (1963a). F. R. agric. Soc. 123, 7 .

Blaxter, K. L. ( $(963 b)$. Int. Congr. Nutr. vi. Edinburgh. (In the Press.)

Blaxter, K. L. \& Graham, N. McC. (1955). Ұ̈. agric. Sci. 46, 292.

Blaxter, K. L. \& Joyce, J. P. (I964). Brit. F. Nutr. 18, 5.

Blaxter, K. L., Joyce, J. P. \& Wainman, F. W. (1963). Nature, Lond., 198, i I 5.

Blaxter, K. L. \& Wainman, F. W. (1964). F. agric. Sci. (In the Press.)

Blaxter, K. L., Wainman, F. W. \& Wilson, R. S. (I96I). Anim. Prod. 3, 5 I.

Blaxter, K. L. \& Wilson, R. S. (1963). Anim. Prod. 5, 27.

Campling, R. C. (1964). Proc. Nutr. Soc. 23, 80.

Clapperton, J. L. (196I). Proc. Nutr. Soc. 20, xxxi.

Clapperton, J. L. (1964). Brit. F. Nutr. r8, 47.

Coop, I. E. \& Hill, M. K. (1962). F. agric. Sci. 58, 187.

Corbett, J. L., Langlands, J. P. \& Boyne, A. W. (I96I). Int. Congr. Anim. Prod. vilı. Hamburg, Vol. 3 , p. 245 .

Ellis, G. H., Matrone, G. \& Maynard, L. A. (1946). F. Anim. Sci. 5, 285.

Graham, N. McC. (1962). Nature, Lond., r96, 289.

Hall, W. C. \& Brody, S. (1934). Res. Bull. Mo. agric. Exp. Sta. no. 208.

Holmes, W., Jones, J. G. W. \& Drake-Brockman, R. M. (I96I). Anim. Prod. 3, 25 I.

Hutton, J. B. (196I). N.Z. F. agric. Res. 4, $5^{8} 3$.

Hutton, J. B. ( (962). N.Z. F. agric. Res. 5, 409.

Lambourne, L. J. (1963). Quoted by Lambourne \& Reardon (1963).

Lambourne, L. J. \& Reardon, T. F. (I963). Aust. F. agric. Res. 14, 272.

Langlands, J. P., Corbett, J. L., McDonald, I. \& Reid, G. W. (I963). Anim. Prod. 5, I I.

Reid, J. T., Smith, A. M. \& Anderson, M. J. (1958). Proc. Cornell Nutr. Conf. Feed Mfrs, p. 88.

Waite, R. \& Gorrod, A. R. N. (1959a). F. Sci. Fd Agric. 10, 308. 
Waite, R. \& Gorrod, A. R. N. (1959b). F. Sci. Fd Agric. ro, 3 I7.

Waite, R., Johnston, M. J. \& Armstrong, D, G. (1964). F. agric. Sci. (In the Press.)

Wallace, L. R. (1956). Proc. int. Grassl. Congr. viI. Wellington, N. Zealand, p. I34.

\section{Ruminal volatile fatty acid production in relation to animal production from grass*}

\section{By J. A. F. Rоoк, National Institute for Research in Dairying, Shinfield, Reading}

The studies of Sir Joseph Barcroft and his colleagues (Phillipson \& McAnally, I942; Barcroft, McAnally \& Phillipson, 1944) at Cambridge in the early I940s established that the volatile fatty acids (VFAs) produced during the fermentation of foodstuffs within the rumen of sheep and cattle are absorbed through the rumen wall and metabolized by the tissues. It has since been shown (see Annison \& Lewis, 1959) that the VFAs arise largely from fermentation of dietary carbohydrates, and of glycerol liberated on hydrolysis of triglycerides, and that only a small part of the soluble carbohydrates escapes degradation. Also, in addition to the major VFAs present in the rumen-acetic, propionic and n-butyric acids-n-valeric acid and branched-chain isomers of butyric and valeric acids (isobutyric, 2-methylbutyric and isovaleric) have been found in low concentrations, more particularly in animals on protein-rich diets (el-Shazly, 1952a,b; Annison, 1954). Formic acid, although undoubtedly an intermediate in the fermentation processes, is rapidly dissimilated in the rumen and is present only in very low concentrations (Johns, I 955 ; Bensadoun, Paladines \& Reid, 1962). Only traces of lactic acid are found in rumen liquor, with the exception of transient high levels shortly after feeding in animals given diets containing large amounts of cooked, starchy foods (Balch \& Rowland, 1957).

\section{The production of volatile fatty acids in the rumen}

There is still uncertainty as to the exact, quantitative contribution of the acids to energy nutrition in ruminant animals. Hogan \& Phillipson ( 1960 ), from measurements of the flow of digesta in adult sheep given a diet of meadow hay (9 parts), linseed meal (4 parts) and oats ( 2 parts), calculated that, of the apparently digested material of the diet, $70 \%$ left the digestive tract between the mouth and the pylorus. The high energy loss in fermentation, as methane as well as direct heat loss, compared with that in other digestive processes would mean that a smaller proportion of the total absorbed nutrients would be accounted for by the materials absorbed from the rumen, which are mainly VFAs. Small quantities of VFAs are produced also in the hind gut.

A more direct approach to the problem is to measure the ruminal production of VFAs. Because of the continuous production and absorption of the acids and the onward passage of digesta this measurement has proved technically difficult, but various approaches have been devised.

* Read at the joint meeting of The Nutrition Society and the British Grassland Society in London on 5 December 1963. Also published in the Fournal of the British Grassland Society, Vol. 19, No. I, March 1964. 